\title{
PAPER
}

\section{Effect of gate structures on the DC and RF performance of AIGaN/GaN HEMTs}

To cite this article: Ahmet Toprak et al 2018 Semicond. Sci. Technol. 33125017

View the article online for updates and enhancements.

\section{IOP ebooks}

Bringing you innovative digital publishing with leading voices

to create your essential collection of books in STEM research.

Start exploring the collection - download the first chapter of every title for free. 


\title{
Effect of gate structures on the DC and RF performance of AIGaN/GaN HEMTs
}

\author{
Ahmet Toprak $^{1,2}{ }^{\oplus}$, Sinan Osmanoğlu ${ }^{1}$, Mustafa Öztürk ${ }^{1}$, Doğan Yılmaz ${ }^{1}$, \\ Ömer Cengiz ${ }^{1}$, Özlem Şen ${ }^{3}$, Bayram Bütün ${ }^{1}{ }^{1}$, Şadan Özcan ${ }^{2,4}$ and \\ Ekmel Özbay ${ }^{1,5}$ \\ ${ }^{1}$ Nanotechnology Research Center, Bilkent University, 06800 Ankara, Turkey \\ ${ }^{2}$ Department of Nanotechnology and Nanomedicine, Hacettepe University, 06532 Ankara, Turkey \\ ${ }^{3}$ Filkon Electronic, Üniversiteler Mh., Galyum Blok D:B-05, 06800 Ankara, Turkey \\ ${ }^{4}$ Department of Physics Engineering, Hacettepe University, 06800 Beytepe, Ankara, Turkey \\ ${ }^{5}$ Department of Electrical and Electronics Engineering, Department of Physics, UNAM-Institute of \\ Materials Science and Nanotechnology, Bilkent University, 06800 Ankara, Turkey \\ E-mail: atoprak@bilkent.edu.tr
}

Received 6 July 2018, revised 4 October 2018

Accepted for publication 26 October 2018

Published 13 November 2018

\begin{abstract}
This work analyzes the effect of various gate structures on the DC and radio frequency (RF) performance of AlGaN/GaN high-electron mobility transistors (HEMTs). AlGaN/GaN HEMT devices with a $3 \mu \mathrm{m}$ drain-to-source spacing, $125 \mu \mathrm{m}$ gate width and $0.3 \mu \mathrm{m}$ gate length in various gate structures were fabricated to achieve the desired frequency response with a robust, high yield, and repeatable process. The maximum drain current $\left(\mathrm{I}_{\mathrm{DS}}, \max \right)$, maximum $\mathrm{DC}$ transconductance $\left(g_{m}\right)$, pinch-off voltage $\left(V_{t h}\right)$, current-gain cutoff frequency $\left(f_{T}\right)$, maximum oscillation frequency $\left(f_{\max }\right)$, and RF characteristics of the devices in terms of the small-signal gain and $\mathrm{RF}$ output power $\left(\mathrm{P}_{\text {out }}\right)$ at $8 \mathrm{GHz}$ were investigated. The results showed that the output power is increased by $1 \mathrm{~dB}$ when the gate structure is changed from field plate to gamma gate. The $V_{\text {th }}, g_{m}, f_{T}$ and $f_{\max }$ values are maximized when the thickness of the passivation layer between the gate foot and the gate head is minimized. It is shown that the $\mathrm{I}_{\mathrm{DS} \text {,max }}$ is decreased and $\mathrm{P}_{\text {out }}$ is increased when the gate recess etching process is performed.
\end{abstract}

Keywords: AlGaN, GaN, high-electron mobility transistor (HEMT), field plate, gamma gate, recessed gate

(Some figures may appear in colour only in the online journal)

\section{Introduction}

Gallium-nitride $(\mathrm{GaN})$ based high-electron mobility transistors (HEMTs) on SiC devices have attracted much attention for high radio frequency $(\mathrm{RF})$ power applications due to their highly demanded physical and electrical properties, such as high current density, high breakdown voltage, high thermal conductivity, and high saturation velocity compared to GaAs based HEMTs [1-3]. GaN based HEMTs are also suitable for coplanar waveguide (CPW) passive technology [2]. AlGaN/ GaN HEMT technology is relatively new compared to $\mathrm{Si}$ and GaAs and there are still difficulties in manufacturing these devices with a robust process for high frequencies and high powers. In this work, we have investigated the effects of the different types of gate present in the literature for the same epitaxial structure, drain-source distance, gate length, and field plate length, under the same measurement conditions. Previously in the literature, various gate structures such as I-gate or standard gate structure [4], gate connected field plate [5], gamma $(\Gamma)$ gate $[6,7], \Gamma$-gate-recessed structure [8] and $\Gamma$-gate with air gap structure $[9,10]$ were investigated. In this work, the structures investigated are named as follows: Type1 refers to an I-gate, Type- 2 refers to an I-gate containing a gate connected field plate; Type- 3 refers to a SiN-passivated $\Gamma$-gate obtained using dry etch techniques, Type- 4 refers to a $\Gamma$-gate obtained using electron beam lithography methods, and Type-5 refers to a $\Gamma$-gate with air gap structure. Wu et al [5] reported that at $8 \mathrm{GHz}$, an output power density of 
$30.6 \mathrm{~W} \mathrm{~mm}^{-1}$, power added efficiency (PAE) of $49.6 \%$ and a gain of $10.7 \mathrm{~dB}$ at a bias of $120 \mathrm{~V}$ were achieved for a gate similar to Type-2 with an $\mathrm{L}_{\mathrm{G}}$ of $550 \mathrm{~nm}$ and $\mathrm{L}_{\mathrm{F}}$ of $900 \mathrm{~nm}$. Wang et al [8] reported that at $8 \mathrm{GHz}$, an output power density of $9.05 \mathrm{~W} \mathrm{~mm}^{-1}$, a PAE of $36.4 \%$, a gain of $5.6 \mathrm{~dB}$, a current gain cut-off frequency of $24 \mathrm{GHz}$ and an maximum oscillation frequency of $34 \mathrm{GHz}$ at a bias of $40 \mathrm{~V}$ were achieved for a gate similar to Type- 3 with an $\mathrm{L}_{\mathrm{G}}$ of $350 \mathrm{~nm}$. Pei et al [10] reported that at $10 \mathrm{GHz}$, an output power density of $3 \mathrm{~W} \mathrm{~mm}^{-1}$, a PAE of $70 \%$ at a bias of $20 \mathrm{~V}$ were achieved for a gate similar to Type-5 with an $\mathrm{L}_{\mathrm{G}}$ of $200 \mathrm{~nm}$.

Although reports on devices containing solely field plates or gamma gates exist, a report comparing different gate structures with the same epitaxial structure, drain-source distance, gate length and field plate length, under the same set of high power and high frequency conditions does not, which we believe is the significance of our report. Maximum drain current, maximum DC transconductance, pinch-off voltage, current-gain cutoff frequency, maximum oscillation frequency, small-signal gain, RF output power (at $8 \mathrm{GHz}$ ), and efficiency of $\mathrm{AlGaN} / \mathrm{GaN}$ HEMTs are presented. AlGaN/ GaN HEMTs are fabricated using CPW technology with a $3 \mu \mathrm{m}$ drain-to-source spacing, $125 \mu \mathrm{m}$ gate width, and $0.3 \mu \mathrm{m}$ gate (foot) length $\left(\mathrm{L}_{\mathrm{G}}\right)$ in various gate structures to achieve the desired frequency response with a robust, high yield, and repeatable process.

\section{Device realization}

The AlGaN/GaN HEMT structure was grown on a $2^{\prime} 6 \mathrm{H}-\mathrm{SiC}$ substrate in a low-pressure metal-organic chemical vapor deposition reactor (Aixtron 200/4 RF-S). Trimethylgallium (TMGa), trimethylaluminum (TMAl), trimethylindium (TMIn), and ammonia (NH3) were used as Ga, Al, In, and N precursors, respectively. Prior to epitaxial growth, the substrate was annealed at $1150{ }^{\circ} \mathrm{C}$ for $10 \mathrm{~min}$ in a hydrogen environment to remove the surface contaminants. The growth of the HEMT structure was initiated with a $20 \mathrm{~nm}$-thick low temperature AlN nucleation layer. Then, a $270 \mathrm{~nm}$ thick high temperature (HT) AlN buffer layer was grown at $1150{ }^{\circ} \mathrm{C}$ followed by a $1200 \mathrm{~nm}$ low pressure carbon doped $\mathrm{GaN}$ buffer. Subsequently, a $300 \mathrm{~nm}$ thick nominally undoped $\mathrm{GaN}$ buffer (2) layer was grown at $1090{ }^{\circ} \mathrm{C}$. After that, a $110 \mathrm{~nm}$ high mobility $\mathrm{GaN}$ channel was grown at $1120^{\circ} \mathrm{C}$ at a higher pressure than the carbon doped $\mathrm{GaN}$ buffer. Active layers were formed with a $1 \mathrm{~nm}$ thick AlN spacer layer and a $20 \mathrm{~nm}$ thick undoped $\mathrm{AlGaN}$ barrier layer at $1150^{\circ} \mathrm{C}$ with a $28 \% \mathrm{Al}$ composition. Epitaxial growth was completed with a $3 \mathrm{~nm}$ thick GaN cap layer at the same temperature with the AlGaN barrier [11-19]. The cross-section of the AlGaN/GaN HEMTs on $6 \mathrm{H}-\mathrm{SiC}$ structure is shown in figure 1 .

The electrical properties of the two-dimensional electron gas (2DEG) were measured with a contactless microwave Hall effect system. The grown HEMT structure exhibited the 2DEG mobility of $1877 \mathrm{~cm}^{2} /$ V.s with a sheet charge density of $1.270 \times 10^{13} / \mathrm{cm}^{2}$ and as low as a $262 \Omega /$ sq. sheet resistance at room temperature.

\begin{tabular}{|lr|}
\hline GaN cap & $3 \mathrm{~nm}$ \\
\hline $\mathrm{Al}_{0.28} \mathrm{Ga}_{0.72} \mathrm{~N}$ barrier & $20 \mathrm{~nm}$ \\
\hline AIN spacer layer & $1 \mathrm{~nm}$ \\
\hline GaN channel & $110 \mathrm{~nm}$ \\
\hline GaN buffer (2) & $300 \mathrm{~nm}$ \\
\hline GaN buffer (1) & $1200 \mathrm{~nm}$ \\
\hline HT-AIN nucleation & $270 \mathrm{~nm}$ \\
\hline LT-AIN nucleation & $20 \mathrm{~nm}$ \\
\hline 6H-SiC Substrate & $2 "$ \\
\hline
\end{tabular}

Figure 1. Cross sectional structure of the $\mathrm{AlGaN} / \mathrm{GaN}$ HEMTs on SI $6 \mathrm{H}-\mathrm{SiC}$ grown by MOCVD.

The schematics of AlGaN/GaN HEMTs with various gate structures are given in figure 2. Gate head lengths $\left(\mathrm{L}_{\mathrm{H}}\right)$ are designed at $1.1 \mu \mathrm{m}$ to obtain a $0.6 \mu \mathrm{m}$ field plate length $\left(\mathrm{L}_{\mathrm{F}}\right)$. Gate length $\left(\mathrm{L}_{\mathrm{G}}\right)$, gate to source distance $\left(\mathrm{L}_{\mathrm{GS}}\right)$, and gate to drain distance $\left(\mathrm{L}_{\mathrm{GD}}\right)$ are chosen to be $0.3 \mu \mathrm{m}, 0.8 \mu \mathrm{m}$, and $1.9 \mu \mathrm{m}$, respectively, to achieve a high yield, and repeatable process. The characterized HEMT devices have a $1 \mathrm{~mm}$ total gate width in the $8 \times 125 \mu$ m configuration.

The fabrication process started with mesa isolation etching and ohmic contact formation for the entire device. Mesa etching was performed with an inductively coupled plasma reactive ion etching (ICP-RIE) system by using $\mathrm{Cl}_{2} / \mathrm{BCl}_{3}$ plasma-based dry etch. The mesa's height was measured as $85 \mathrm{~nm}$ by a using surface profilometer. For ohmic contact formation, a $\mathrm{Ti} / \mathrm{Al} / \mathrm{Ni} / \mathrm{Au}$ metal stack was deposited by using an electron beam evaporator (EBE) system with the thicknesses of $12,120,35$, and $65 \mathrm{~nm}$, respectively. The metal stack was annealed in a nitrogen atmosphere at $850{ }^{\circ} \mathrm{C}$ for $30 \mathrm{~s}$. After ohmic contacts were formed, TLM measurements were completed using the four-point probe method. The measured ohmic contact resistance was

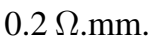

Since the gates of all the devices were in different forms, the fabrication steps for gate contact were different for each device.

In order to pattern the gate feet regions of the samples, different fabrication steps were applied. A Type- 3 device and Type-5 device were passivated with a $200 \mathrm{~nm}$-thick $\mathrm{Si}_{3} \mathrm{~N}_{4}$ layer grown by a plasma-enhanced chemical vapor deposition (PECVD) system before the formation of the gate pattern. Then, for only a Type-5 device, $80 \mathrm{~nm}$ Germanium (Ge) metal was deposited by using EBE over the passivation layer. Type- 1 and Type- 2 devices were covered with PMMA $950 \mathrm{~K}$ A6, the Type-3 and Type-5 devices were covered with ZEP $520 \mathrm{~A}$, and the Type-4 device was covered with three 


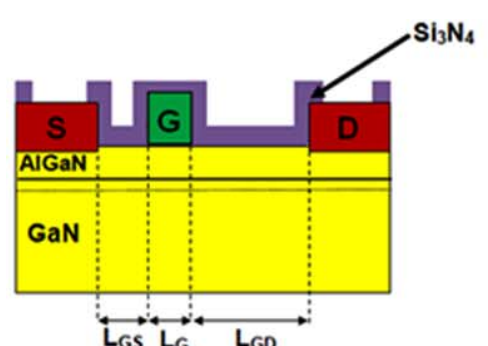

(a)

Type-1

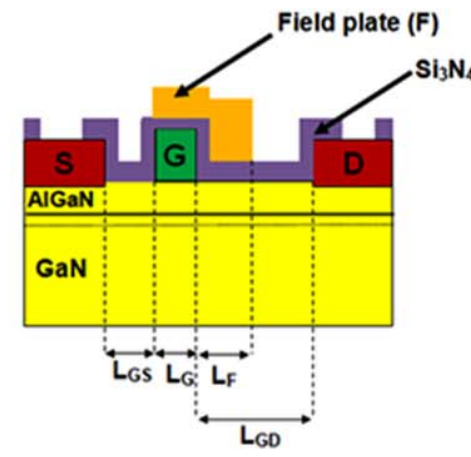

(b)

Type-2
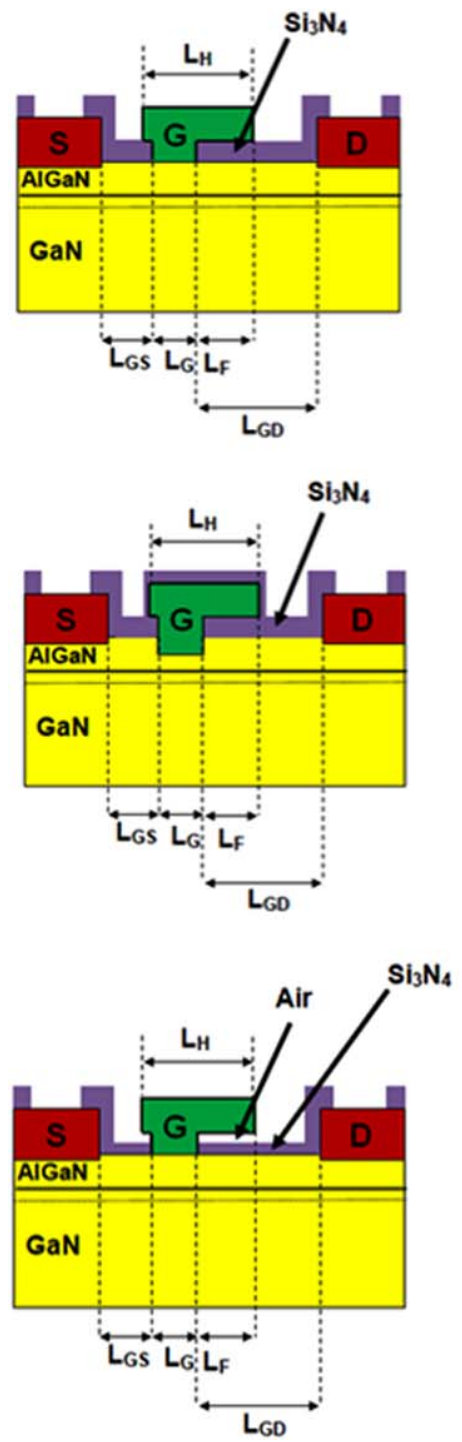

(e)

Type- 5

Figure 2. Schematic of $\mathrm{AlGaN} / \mathrm{GaN}$ HEMTs with various gate structures. additional layers of electron beam resists, PMMA $950 \mathrm{~K} \mathrm{A4}$, MAA EL13 copolymer and then PMMA $50 \mathrm{~K}$ A5. Then, in order to define the gate feet, all of the devices were patterned with direct electron-beam lithography with a single exposure. The feet regions of the Type- 3 device and Type- 5 device were formed by means of dry etching of ICP-RIE with an $\mathrm{SF}_{6} / \mathrm{Ar}$ gas mixture.

In order to form the gate head pattern, the Type- 3 device and Type-5 device were covered with PMMA $950 \mathrm{~K}$ A6 and electron beam lithography was used to define the gate heads. For only the Type- 4 device, $5 \mathrm{~nm}$ recess etching was done by using $\mathrm{CI}_{2} / \mathrm{BCI}_{3}$ plasma based dry etch for the Type- 4 gate structure.

Thereafter, all of the samples' gate feet and head regions were deposited with an $\mathrm{Ni} / \mathrm{Au}$ metal stack by using the EBE system with thicknesses of 50 and $300 \mathrm{~nm}$, respectively. After this step, Ge wet etching was done with a $10 \% \mathrm{H}_{2} \mathrm{O}_{2}$ solution for only the sample with a Type 5 gate structure.

As the next step in fabrication, the devices without a passivation layer, i.e. Type-1, Type- 2 and Type- 4 devices, were passivated with a $300 \mathrm{~nm}$-thick $\mathrm{Si}_{3} \mathrm{~N}_{4}$ layer using the PECVD system. Then, the openings, where the field plates and interconnected metals would be deposited, were formed by means of the dry etching of the ICP-RIE system with $\mathrm{SF}_{6}$ and Ar gas mixtures.

After this step the Type-2 device with a field plate had its gate structure covered with ZEP $520 \mathrm{~A}$ and patterned with direct electron-beam lithography with a single exposure to define the field plate. Then, these regions were deposited with a Ti/Au metal stack by using the EBE system with thicknesses of 15 and $340 \mathrm{~nm}$, respectively, for field plate metalization formation. SEM images of gate structures are given in figure 3.

For all of the devices, the air bridge post structures were constituted to reduce the parasitics between cross-overs and for preventing a short circuit of the metals by functioning as a jumper. Finally, a Ti/Au metal stack with a total thickness of $2.2 \mu \mathrm{m}$ had been deposited as an interconnection using the EBE system, and the fabrication process was completed with this last step. Figure 4 shows a completed device's optical microscope image.

\section{Results}

DC measurements were performed using a parametric semiconductor device analyzer. Figure 5 shows the $\mathrm{I}_{\mathrm{D}}-\mathrm{V}_{\mathrm{GS}}$ characteristics for devices with different gate structures. The pinch off-voltages $\left(\mathrm{V}_{\mathrm{th}}\right)$ are $-3.8 \mathrm{~V}$ for the Type-1 device, $-3.7 \mathrm{~V}$ for the Type-2 device, $-3.0 \mathrm{~V}$ for the Type- 3 device, $-3.2 \mathrm{~V}$ for the Type- 4 device, and $-1.9 \mathrm{~V}$ for the Type- 5 device.

Figure 6 shows the $I_{D S}-V_{D S}$ characteristics for devices with different gate structures. The maximum current densities $\left(\mathrm{I}_{\mathrm{DS}}, \max \right)$ are $1.1 \mathrm{~A} \mathrm{~mm}^{-1}$ for the Type- 1 device, $1.0 \mathrm{~A} \mathrm{~mm}^{-1}$ for the Type- 2 and Type- 3 devices, $0.9 \mathrm{~A} \mathrm{~mm}^{-1}$ for the Type4 device, and $0.88 \mathrm{~A} \mathrm{~mm}^{-1}$ for the Type-5 device.

Figure 7 shows the $g_{m}-V_{G S}$ characteristics of the devices for different gate structures. The peak transconductance 

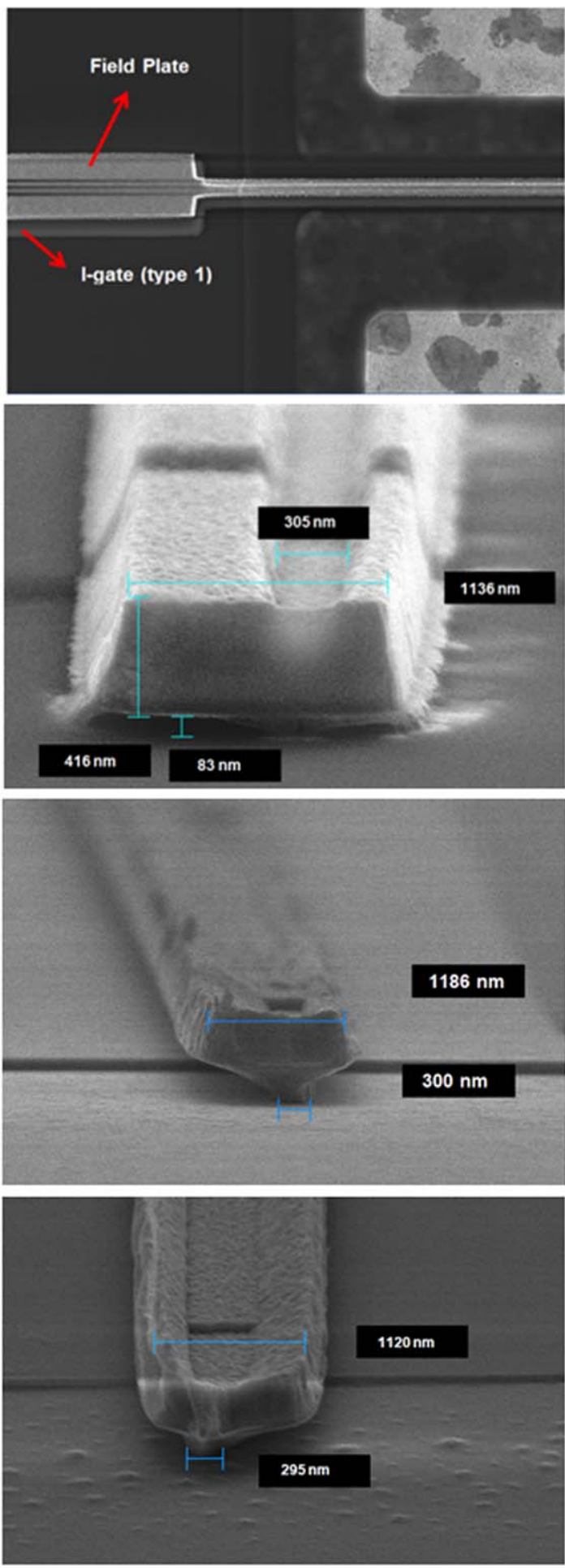

Figure 3. SEM images of gate structures.

values for the devices are $0.29 \mathrm{~S} \mathrm{~mm}^{-1}$ for the Type- 1 device, $0.25 \mathrm{~S} \mathrm{~mm}^{-1}$ for the Type- 2 device, $0.29 \mathrm{~S} \mathrm{~mm}^{-1}$ for the Type-3 device, $0.28 \mathrm{~S} \mathrm{~mm}^{-1}$ for the Type-4 device, and $0.33 \mathrm{~S} \mathrm{~mm}^{-1}$ for the Type-5 device.

On-wafer small-signal measurements were carried out in the $1-20 \mathrm{GHz}$ frequency range. The devices were biased at drain to source voltage, $\mathrm{V}_{\mathrm{DS}}=25 \mathrm{~V}$ and drain to source current $\mathrm{I}_{\mathrm{DS}}=100 \mathrm{~mA} \mathrm{~mm}^{-1}$. Short-circuit current-gain $\left|\mathrm{h}_{21}\right|$

Type-3

(c)

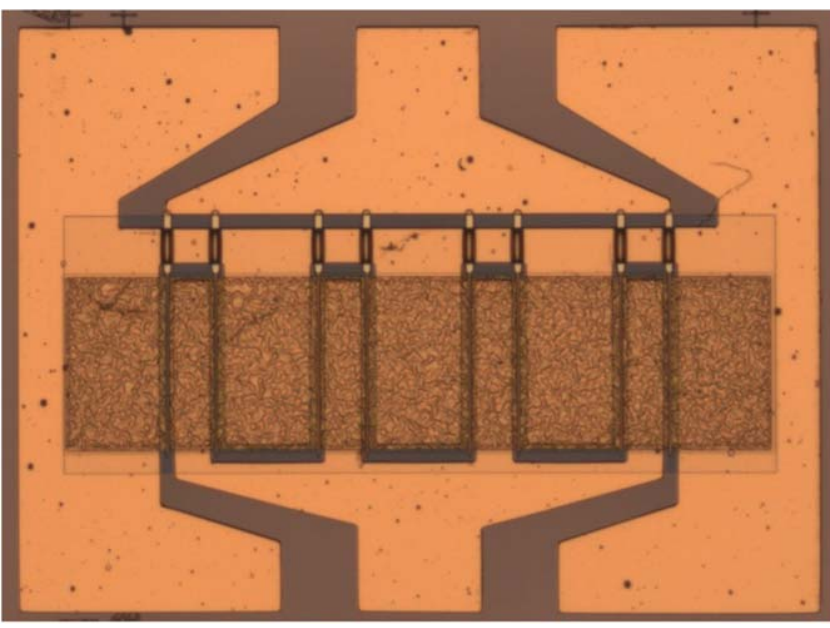

Figure 4. Optical microscope image of fabricated HEMTs.

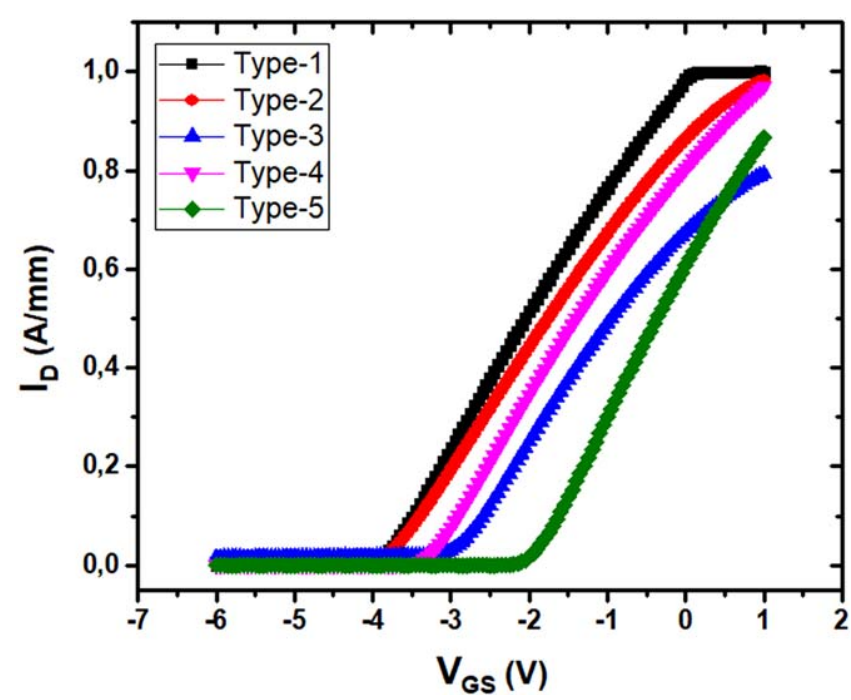

Figure 5. Comparison of the pinch off-voltage $\left(\mathrm{V}_{\mathrm{th}}\right)$ characteristics of $\mathrm{AlGaN} / \mathrm{GaN}$ HEMTs with various gate structures.

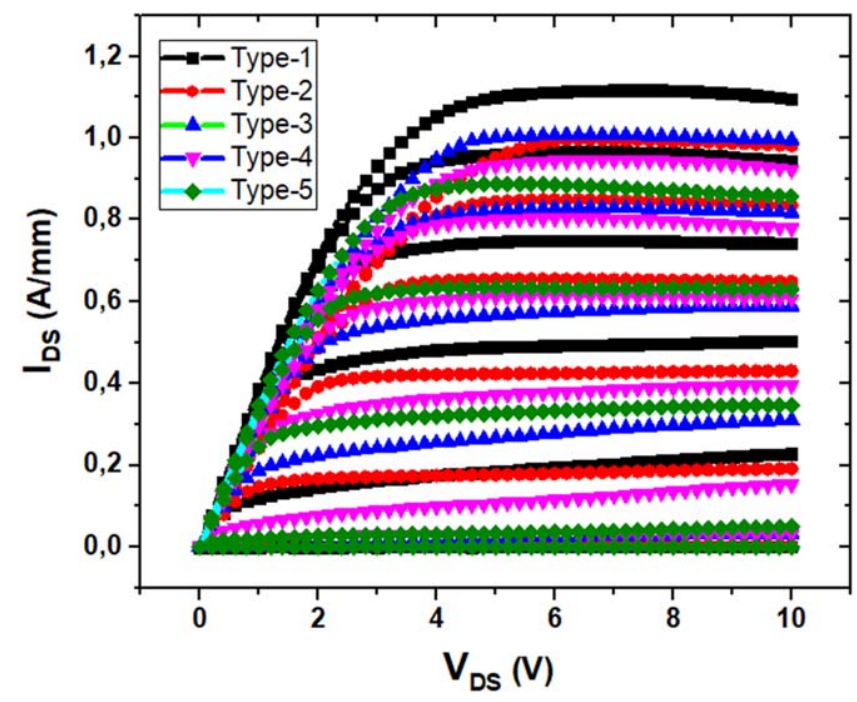

Figure 6. Comparison of the drain current-voltage $\left(\mathrm{I}_{\mathrm{DS}}-\mathrm{V}_{\mathrm{DS}}\right)$ characteristics of $\mathrm{AlGaN} / \mathrm{GaN}$ HEMTs with various gate structures. 


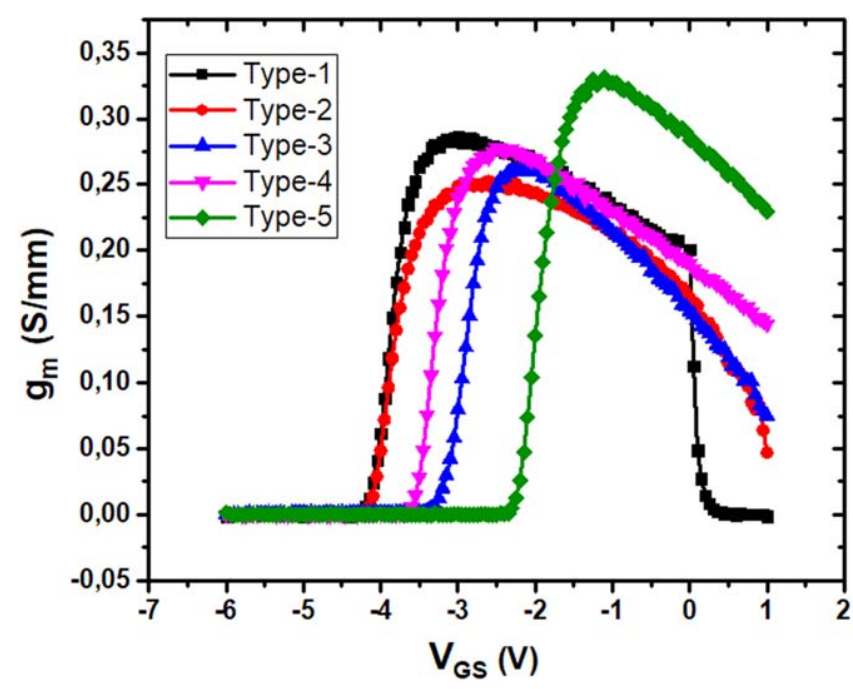

Figure 7. Comparison of transconductance $\left(\mathrm{g}_{\mathrm{m}}-\mathrm{V}_{\mathrm{GS}}\right)$ characteristics of $\mathrm{AlGaN} / \mathrm{GaN}$ HEMTs with the various gate structures.

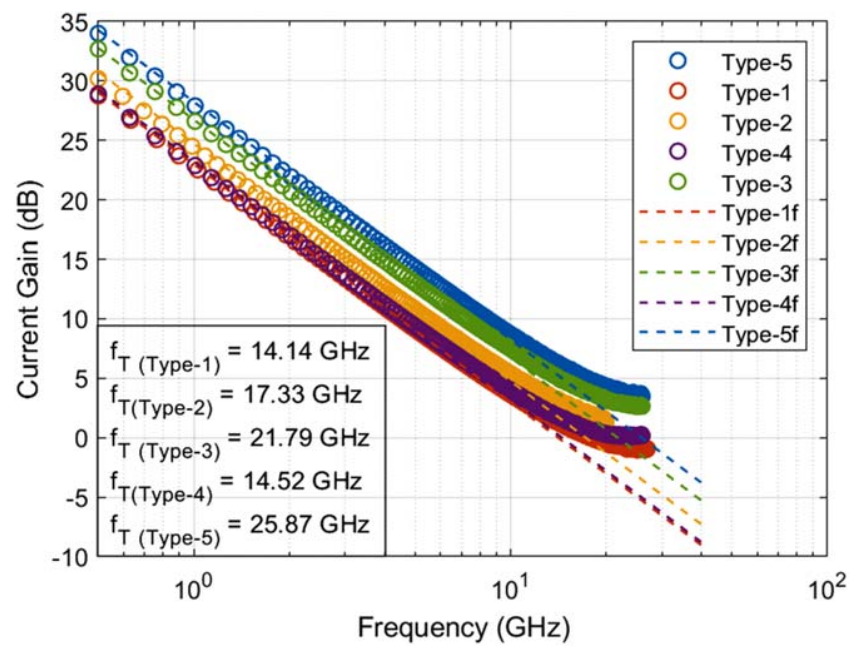

Figure 8. Comparison of short-circuit current-gain $\left|\mathrm{h}_{21}\right|$ of $\mathrm{AlGaN} /$ GaN HEMTs with the various gate structures. Devices were biased at $\mathrm{V}_{\mathrm{DS}}=25 \mathrm{~V}$ with $\mathrm{I}_{\mathrm{DS}}=100 \mathrm{~mA} \mathrm{~mm}^{-1}$.

and Mason's unilateral power-gain $\mathrm{U}_{\mathrm{G}}$ were derived from onwafer S-parameter measurements as a function of frequency (figures 8 and 9). The unity current-gain cutoff frequencies, $\mathrm{f}_{\mathrm{T}}$ are $14.14 \mathrm{GHz}, 17.33 \mathrm{GHz}, 21.79 \mathrm{GHz}, 14.52 \mathrm{GHz}$ and $25.87 \mathrm{GHz}$ for the Type-1, Type-2, Type-3, Type-4, and Type-5 devices, respectively. The maximum oscillation frequency $\mathrm{f}_{\max }$ are $35.5 \mathrm{GHz}, 28.2 \mathrm{GHz}, 44.65 \mathrm{GHz}, 35.45 \mathrm{GHz}$ and $53.1 \mathrm{GHz}$ for the Type-1, Type-2, Type-3, Type-4, and Type- 5 devices, respectively.

Large-signal measurements were performed using an automated load pull system at $8 \mathrm{GHz}$. The data were taken onwafer at room temperature without any thermal management. HEMTs were measured at $100 \mathrm{~mA} \mathrm{~mm}^{-1}$ drain to source current with $25 \mathrm{~V}$ drain bias and the output power, smallsignal gain and power added efficiency (PAE) values were obtained (figure 10-14). Small-signal gains are $10.3 \mathrm{~dB}$, $10.3 \mathrm{~dB}, 9.7 \mathrm{~dB}, 8.8 \mathrm{~dB}$ and $12.7 \mathrm{~dB}$; output powers at $2 \mathrm{~dB}$ gain compression are $35.3 \mathrm{dBm}\left(3.4 \mathrm{~W} \mathrm{~mm}^{-1}\right), 36.5 \mathrm{dBm}$

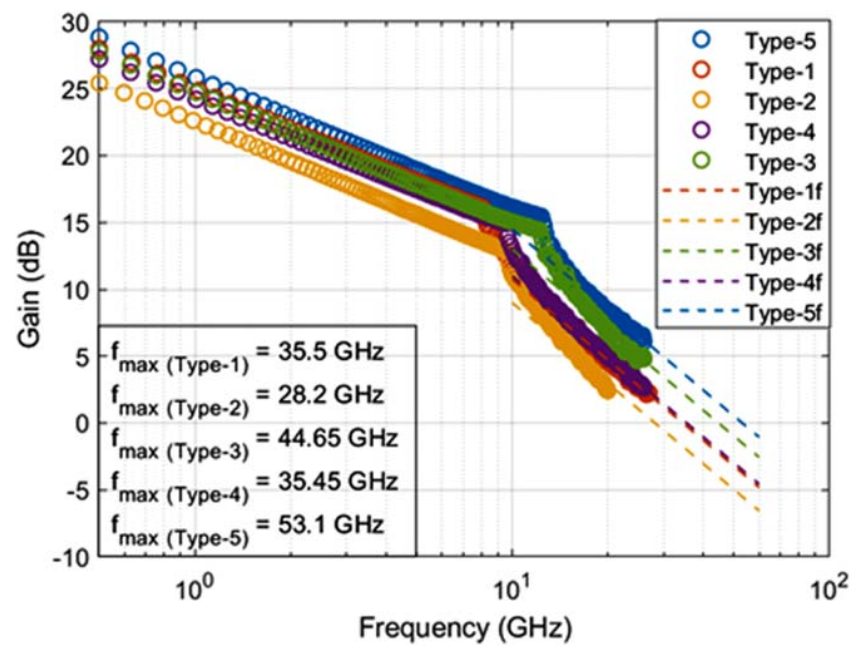

Figure 9. Comparison of Mason's unilateral power-gain $U_{G}$ of $\mathrm{AlGaN} / \mathrm{GaN}$ HEMTs with the various gate structures. Devices were biased at $\mathrm{V}_{\mathrm{DS}}=25 \mathrm{~V}$ with $\mathrm{I}_{\mathrm{DS}}=100 \mathrm{~mA} \mathrm{~mm}^{-1}$.

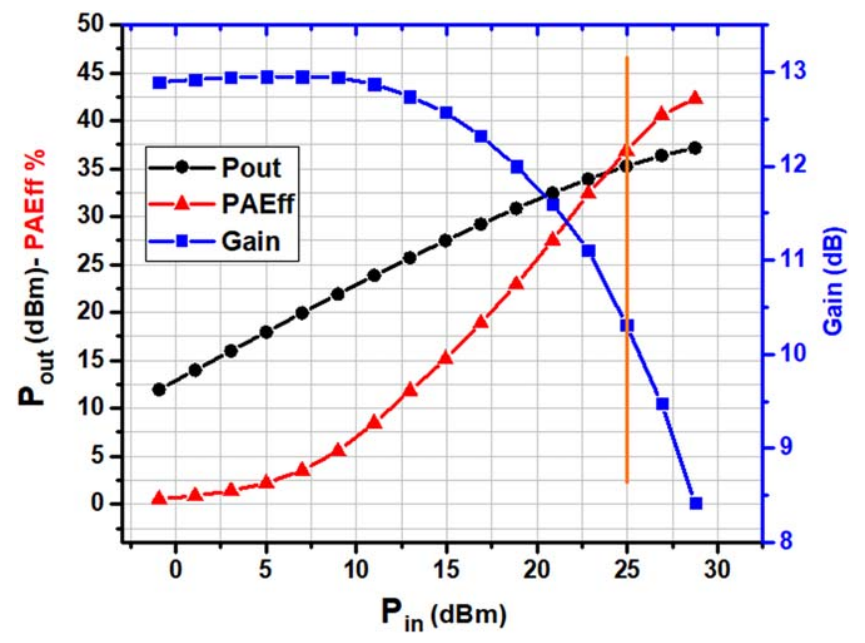

Figure 10. Large-signal performance of $\mathrm{AlGaN} / \mathrm{GaN}$ HEMTs with Type- 1 gate structures.

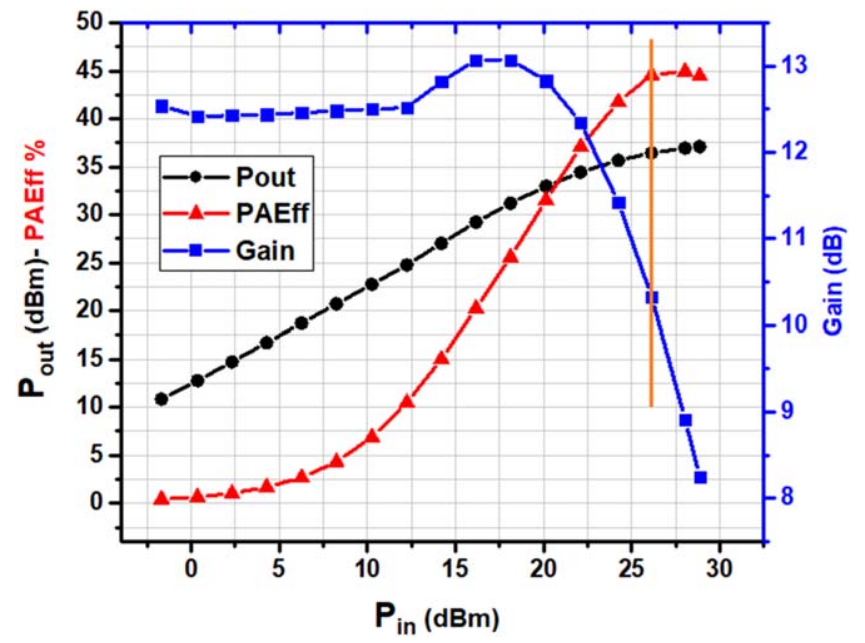

Figure 11. Large-signal performance of AlGaN/GaN HEMTs with the Type- 2 gate structures. 


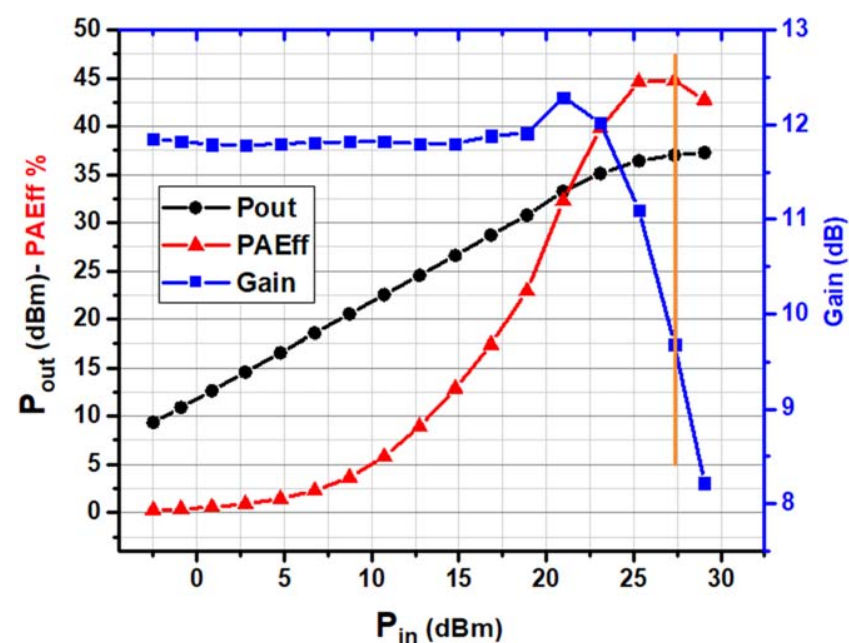

Figure 12. Large-signal performance of $\mathrm{AlGaN} / \mathrm{GaN}$ HEMTs with the Type-3 gate structures.

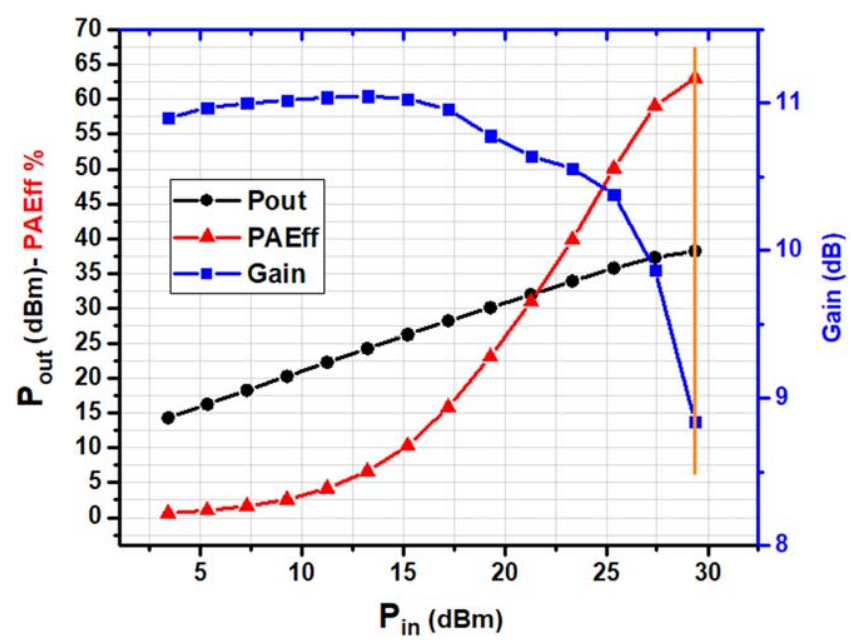

Figure 13. Large-signal performance of $\mathrm{AlGaN} / \mathrm{GaN}$ HEMTs with the Type-4 gate structures.

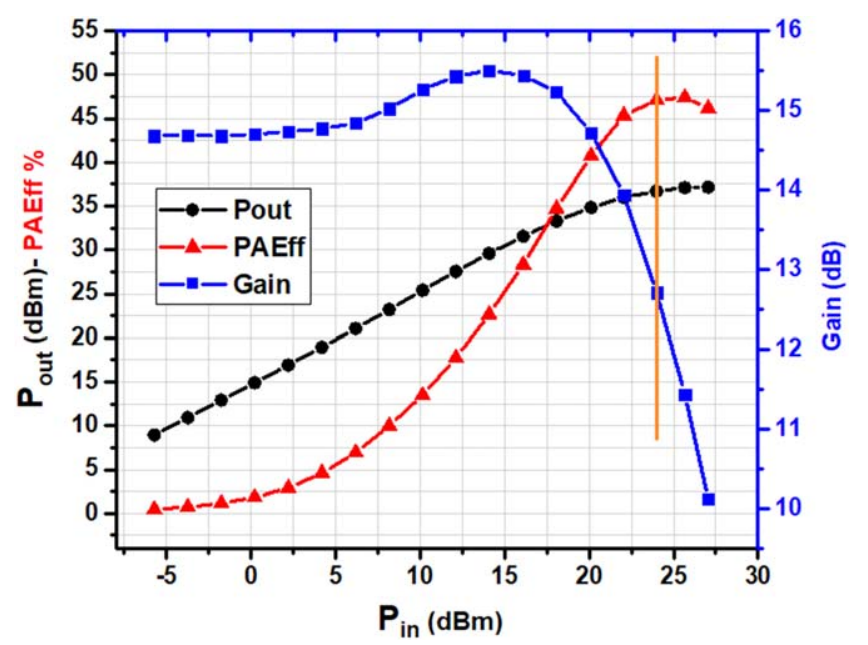

Figure 14. Large-signal performance of $\mathrm{AlGaN} / \mathrm{GaN}$ HEMTs with the Type-5 gate structures.
Table 1. Summary of the results of the AlGaN/GaN HEMTs devices with the various gate structures.

\begin{tabular}{lccccc}
\hline Gate Structure & Type-1 & Type-2 & Type-3 & Type-4 & Type-5 \\
\hline $\mathrm{I}_{\mathrm{DS}, \max }$ & 1.1 & 1.0 & 1.0 & 0.9 & 0.88 \\
$\quad\left(\mathrm{~A} \mathrm{~mm}{ }^{-1}\right)$ & & & & & \\
$\mathrm{V}_{\text {th }}(\mathrm{V})$ & -3.8 & -3.7 & -3.0 & -3.2 & -1.9 \\
$\left.\mathrm{~g}_{\mathrm{m}}(\mathrm{S} \mathrm{mm})^{-1}\right)$ & 0.29 & 0.25 & 0.29 & 0.28 & 0.33 \\
$\mathrm{f}_{\mathrm{T}}(\mathrm{GHz})$ & 14.14 & 17.33 & 21.79 & 14.52 & 25.87 \\
$\mathrm{f}_{\max }(\mathrm{GHz})$ & 35.5 & 28.2 & 44.65 & 35.45 & 53.1 \\
$\mathrm{PAE}^{\mathrm{a}}(\%)$ & 36.8 & 44.6 & 44.7 & 63.1 & 47.1 \\
Gain $^{\mathrm{a}}(\mathrm{dB})$ & 10.3 & 10.3 & 9.7 & 8.8 & 12.7 \\
Output Pow- $_{\quad}^{\mathrm{a}}(\mathrm{dBm})$ & 35.3 & 36.5 & 37 & 38.2 & 36.7 \\
$\quad$ Output Power $^{\mathrm{a}}$ & 3.4 & 4.5 & 5.0 & 6.6 & 4.7 \\
(W mm $\left.^{-1}\right)$ & & & & & \\
\hline
\end{tabular}

At $25 \mathrm{~V}, 2 \mathrm{~dB}$ comp.

(4.5 $\left.\mathrm{W} \mathrm{mm}^{-1}\right), \quad 37 \mathrm{dBm} \quad\left(5.0 \mathrm{~W} \mathrm{~mm}^{-1}\right), \quad 38.2 \mathrm{dBm}$ $\left(6.6 \mathrm{~W} \mathrm{~mm}^{-1}\right)$ and $36.7 \mathrm{dBm}\left(4.7 \mathrm{~W} \mathrm{~mm}^{-1}\right)$; PAE (\%) values are $36.8,44.6,44.7,63.1$, and 47.1 for the Type-1, Type-2, Type-3, Type-4, and Type-5 devices, respectively. The DC, small-signal and large-signal results are summarized in table 1 .

\section{Conclusion}

High-quality $\mathrm{AlGaN} / \mathrm{GaN}$ HEMTs on a $6 \mathrm{H}-\mathrm{SiC}$ structure were grown by MOCVD and a study was conducted to examine the effect of various gate structures on the DC and RF performance of $\mathrm{AlGaN} / \mathrm{GaN}$ HEMTs without using hole technology.

With these measurements, it was seen that the $I_{D S}$, max value was the highest and $\mathrm{V}_{\text {th }}$ value was the smallest in AlGaN/GaN HEMTs with a Type-1 gate structure since the absence of a field plate increases gate resistance [20]. The absence of a field plate also decreases the gate to source and gate to drain capacitances (fringing capacitance, $\mathrm{C}_{\mathrm{GF}}$ ) [21] that limit the decrease in $\mathrm{f}_{\max }$, although $\mathrm{f}_{\mathrm{T}}$ of a Type- 1 device is the lowest, and $f_{\max }$ is not. In addition, this absence of a field plate structure also results in the lowest output power density and lowest power added efficiency.

For a Type- 2 device, the gate connected field plate structure decreases gate resistance and intrinsic gate capacitance $\left(\mathrm{C}_{\mathrm{GO}}\right)$ which results in the lowest $\mathrm{g}_{\mathrm{m}}$. However, the field plate structure increases the intrinsic electron velocity $\left(\nu_{e}\right)$ [22] which limits the decrease in the $\mathrm{f}_{\mathrm{T}}$, but the passivation layer between the gate and field plate increases the $\mathrm{C}_{\mathrm{GF}}$ considerably and results in the lowest $f_{\max }$ [21]. This field plate structure increases the output power and efficiency compared to a Type-1 device [5].

In a Type- 3 device, the gamma gate structure increases the $\mathrm{V}_{\mathrm{th}}$, and $\mathrm{g}_{\mathrm{m}}$ and maintains the same $\mathrm{I}_{\mathrm{DS}}$, max compared to Type-2. This means that the gate resistance is smaller and $\mathrm{C}_{\mathrm{GO}}$ is bigger than Type-2. The passivation between the gate head and foot that decreases the $\mathrm{C}_{\mathrm{GF}}$ compared to Type- 1 and results in higher $f_{T}$ and $f_{\max }$. The output power at $2 \mathrm{~dB}$ 
compression of a Type- 3 device is higher than Type- 2 since the $\mathrm{C}_{\mathrm{GF}}$ is smaller and the lack of a passivation layer above the gate head results in better thermal performance, leading to higher output power.

A Type- 4 device is the most preferable when the output power and efficiency are considered. It is observed that a $2 \mathrm{~nm}$ recess etched process into the the $\mathrm{AlGaN}$ barrier layer and placing the Schottky gate directly on the AlGaN barrier layer decreases the $\mathrm{C}_{\mathrm{GO}}$, results in smaller $\mathrm{g}_{\mathrm{m}}$, and increases gate resistance, resulting in the small $\mathrm{V}_{\text {th }}$ compared to a Type3 device. Recess process [23] and the passivation layer over the gate increases $C_{G F}$, which results in smaller $f_{T}$ and $f_{\max }$ compared to a Type- 3 device. The recess process and the passivation over the gate head can be a good alternative in the HEMT fabrication process due to the power performance.

A Type-5 device has the highest $\mathrm{V}_{\text {th }}, \mathrm{g}_{\mathrm{m}}$, small-signal gain, $\mathrm{f}_{\mathrm{T}}$ and $\mathrm{f}_{\max }$ value due to the air under the gate head and above the passivation layer (owing to the lowest $\mathrm{C}_{\mathrm{GF}}$ and highest $\mathrm{C}_{\mathrm{GO}}$ compared to other the gate types) [21, 22]. This fabrication process is a good alternative to increase the high frequency performance of HEMTs without limiting the power performance. It is possible to have high $\mathrm{f}_{T}$ and $\mathrm{f}_{\max }$ values without decreasing the gate length and without decreasing the power performance.

The DC and RF performance of HEMTs devices are strictly dependent on the gate structure. The gate structure and fabrication process should be optimized considering the requirements, robustness and ease of fabrication. Type- 4 devices seem to be the best when power and efficiency are considered. Type- 5 seems the best alternative when operating at a higher small-signal gain without the reduction of power performance being an issue and, in this way, the $f_{\max }$ value increases with a considerably long gate length and the process is robust and repeatable.

\section{Acknowledgments}

One of the authors (E O) acknowledges partial support from the Turkish Academy of Sciences.

\section{ORCID iDs}

Ahmet Toprak (10) https://orcid.org/0000-0003-4879-8296
Bayram Bütün (1) https://orcid.org/0000-0003-0892-4681

\section{References}

[1] Shur M S 1998 Solid-State Electron. 42 2131-8

[2] Mishra U K, Shen L, Kazior T E and Wu Y F 2008 Proc. IEEE 96 287-305

[3] Roccaforte F, Fiorenza P, Greco G, Nigro R L, Giannazzo F, Lucolano F and Saggio M 2018 Microelectron. Eng. 187-188 66-77

[4] Shealy J R, Kaper V, Tilak V, Prunty T, Smart J A, Green B and Eastman L F 2002 J. Phys.: Condens. Matter 143499

[5] Wu Y-F, Saxler A, Moore M, Smith R P, Sheppard S, Chavarkar P M, Wisleder T, Mishra U K and Parikh P 2004 IEEE Electron Device Lett. 25 117-9

[6] Kumar V, Chen G, Guo S and Adesida I 2006 IEEE Trans. Electron Devices $\mathbf{5 3}$ 1477-80

[7] Lin C K, Wang W-K, Hwu M-J and Chan Y-J 2004 J. Vac. Sci. Technol. B 22 1723-6

[8] Wang X L, Chen T S, Xiao H L, Wang C M, Hu G X, Luo W J, Tang J, Guo L C and Li J M 2008 Solid-State Electron. 52 926-9

[9] Palaciosa T, Snow E, Pei Y, Chakraborty A, Keller S, DenBaars S P and Mishra U K 2005 IEEE Int. Electron Devices Meeting (https://doi.org/10.1109/ IEDM.2005.1609472)

[10] Pei Y, Poblenz C, Corrion A L, Chu R, Shen L, Speck J S and Mishra U K 2008 Electron. Lett. 44 (9) 1-2

[11] Amano H, Sawaki N, Akasaki I and Toyoda Y 1986 Appl. Phys. Lett. 48 353-5

[12] Lo C-F et al 2012 J. Vac. Sci. Technol. B 30 (1) 011205

[13] Arslan E, Öztürk M K, Tıraş E, Tıraş T, Özçelik S and Özbay E 2017 J. Mater. Sci. Mater. Electron. 28 3200-9

[14] Wang X L et al 2005 Solid-State Electron. 49 1387-90

[15] Jiménez A et al 2003 Appl. Phys. Lett. 82 (26) 4827-9

[16] Guo L et al 2008 Microelectron. J. 39 777-81

[17] Tilak V et al 2001 IEEE Electron Device Lett. 22

[18] Miyoshi M et al 2004 Japanese J. Appl. Phys. 43 7939-43

[19] Waltereit P et al 2009 J. Appl. Phys. 106 (2) 023535

[20] Greco G, Lucolano F and Roccaforte F 2018 Mater. Sci. Semicon. Proc. 78 96-106

[21] Jessen G H, Fitch R C, Gillespie J K, Via G, Crespo A, Langley D, Denninghoff D J, Trejo M and Heller E R 2007 IEEE Trans. Electron Devices $\mathbf{5 4} 2589-97$

[22] Guerra D, Saraniti M, Ferry D K, Goodnick S M and Marino F A 2011 IEEE Trans. Electron Devices 58 3876-84

[23] Song Bo et al 2014 IEEE Trans. Electron Devices 61 747-54 